\title{
Bodhisattva Jizō and Folk Religious Influences: Elements of Folk Religion in Jizō's Understanding in Japan
}

Iva LAKIĆ PARAĆ *

\begin{abstract}
In this paper I will focus on religious meanings that surround Bodhisattva Jizō and their connection with Japanese traditional folk religious beliefs and practices that have greatly influenced the present-day interpretation of the Jizō phenomena in Japan. Jizō is an ideal case for illustrating the functioning of religious currents in Japan and perfectly reveals how these currents were mutually complementary in the past and how they work today.
\end{abstract}

Keywords: Bodhisattva Jizō, sae no kami, dōsojin, yama no kami, Japanese folk beliefs

\section{Izvleček}

V članku se osredotočam na religiozne pomene, ki spremljajo bodisatvo Jizō, in njihove povezave $\mathrm{z}$ japonskimi tradicionalnimi ljudskimi verovanji in praksami, ki so pomembno vplivali na sodobne interpretacije fenomena Jizō na Japonskem. Jizō je idealen za ponazoritev delovanja religijskih tokov, saj odkriva, kako so se ti tokovi dopolnjevali v preteklosti in kako delujejo danes.

Ključne besede: bodisatva Jizō, sae no kami, dōsojin, yama no kami, ljudska verovanja na Japonskem

Iva LAKIĆ PARAĆ, Department for Indology and Far East Studies,

Chair of Japanology, Faculty of Humanities and Social Sciences,

University of Zagreb, Zagreb, Croatia.

iva_lakic[at]yahoo.it

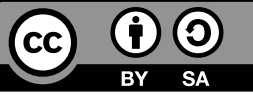




\section{Introduction}

Jizō is ubiquitous in Japan. His statuettes follow you at every turn-while walking on forgotten village roads, entering homes and temples, touring cemeteries, and entering holy places such as mountains or volcanoes. In Buddhist iconography he is presented as a monk with chubby cheeks, while in the Japanese language there is a phrase jizoggao or "the face of Jizö", which means a smiling face with round cheeks, indicating a satisfied person. Since ancient times Jizō was the deity to whom people used to direct the widest variety of prayers. One of the reasons that Jizo is experienced in this specific way in Japan is that, while common people usually perceive Buddhist concepts as somewhat complicate, complex and difficult to understand, the meanings surrounding Jizō are perceived in a simple way understandable to everybody.

Jizō's original name in Sanskrt is Ksitigarbha, consisting of the words ksiti, "earth", and garbha, "uterus". Many Japanese theorists associate Jizō with the Indian goddess of the earth, Prthivi (her name in Sanskrit means "earth" and she is the "Mother Earth", often associated iconographically with the cow), although there are no historical links. He is one of the most beloved and revered Bodhisattvas in East Asian Mahayana Buddhism, in China known as Dizang, in Korea as Jijang Bosal, and in Japan as Jizō Bosatsu.

The religious meanings surrounding this Bodhisattva in Japan have been associated with the most powerful and meaningful items of human existence: procreation and protection of progeny. In this sense, it is interesting to follow the process of his amalgamation and how he grew in importance together with the change of Japanese peoples' understanding of issues concerning human procreation, especially in modern times.

Within the Buddhist pantheon he is one of the eight major Bodhisattvas ${ }^{1}$, beings that are one step from nirvana but delay the final step because they made a vow to help all people in their efforts to get out of samsara ${ }^{2}$. Although they can be

1 Bosatsu or Bodhisattva in early Buddhism, is Buddha in past lives before his enlightenment; in Mahayana Buddhism he is the spiritual ideal, a being on the road to enlightenment that had vowed to stop itself before nirvana out of compassion for other beings. He cherishes perfection, but postpones his full revival until all beings are saved. His main characteristic, together with wisdom, is compassion for beings in samsara (round of rebirth) and with his karmanic merits he can take upon their sufferings. The most famous Bodhisattvas are Avalokiteśvara (Jap. Kannon), Manjushri (Jap. Monju), Samantabhadra (Jap. Fugen), and Kšitigarbha (Jap.Jizō) (Jauk-Pinhak 2001, 109).

2 According to Tibetan Buddhism, the circle of life is made of the middle, where the pig, snake, and rooster (or pigeon) run around, symbolizing folly, hatred, and greed-the passions that keep beings in samsara. Around them there are six worlds or kingdoms, which stand for the six types of existence. All the beings are categorized according to their merits: celestial beings dwell on the top, on their sides there are demons and people, above them there are animals and hungry ghosts, and at the bottom there are inhabitants of hell (Jauk-Pinhak 2001,107). 
compared with the Christian saints, the difference is, inter alia, in the fact that the latter have already entered the stage of eternal bliss (Jauk-Pinhak 2001, 109).

Before coming to Japan, Jizō appeared in India, and naturally in China, presumably sometime in the 7th century. Jizo becomes more popular in China only in the 9th century while in Japan his cult will flourish in Kamakura period. Although there are similarities, there are also big differences in Jizôs's cult in China and Japan. The first and the main difference is in the attitude towards this deity among the people; the Japanese feel closeness and accessibility, while in China such a relationship towards the "lord of the underworld" does not exist (see De Visser 1912).

Why such an attitude of the Japanese towards Jizō? My assumption is that Jizō's popularity and his overwhelming presence in Japan are due to the fact that his worship contains many elements of Japanese folk religious practices and beliefs.

This relationship was determined by his associations with the popular local folk deities, such as dosojina and sae no kami, and Jizō is actually worshiped in the manner of ancient Japanese folk deities. In my opinion, the Jizō Bodhisattva amalgamation illustrates well how Buddhism adapted to the needs of Japanese people through history, but, even more importantly, it also shows the persistence of attitude that Japanese people have toward their popular traditional deities and beliefs.

People who studied Jizō cults in Japan know how vast and multiple this field actually is and explaining it all would be a rather difficult task for one article. Accordingly I decided not to touch on the present Jizō practices in depth. Instead, I will focus on what I was told by my Japanese sources during the Yamagata stay, more precisely, on their attitude toward this Bodhisattva. My attempt in this paper is to investigate the traditional historical and axiological background represented by the folk religious influences and to search for the reasons of that attitude inside the traditional non-Buddhist practices and beliefs.

\section{Fieldwork Research in Yamagata Prefecture}

During my ethnographic fieldwork research in Yamagata prefecture in $2006 \mathrm{I}$ had an opportunity to grasp some of the Japanese religious practices in sito. The goal of my research was to find out what Jizō matsuri looked like in the past (see Lakić Parać 2013), but the collateral findings of the research included discerning the attitude ordinary people have toward Jizo. I was interviewing the village people about their opinion on this deity and found out that they have a rather close and warm relationship with him. They prayed to Jizō on a variety of occasions, and they all felt closeness to this Bodhisattva. 
Summarizing my fieldwork research results, today, there are no official religious ceremonies dedicated to Jizō in the Yamagata villages I stayed in (Higashihorikoshi and Soegawa), and omairi (visiting the graves of the deceased) is held on every 24th day of the month, but not as a special festival. But in the past, according to my Japanese informers, the festival was held on April, August, and December 23rd. When I asked them why the 23rd day of the month, they did not know, but I found out later that the date was connected with the custom of visiting the graves of the deceased during the spring and autumn equinox (March 23rd and September 23rd). These rituals follow the lunar calendar, which is approximately one month ahead of the Western calendar (used in Japan since 1873).

The ritual that was held on April 23rd was called The Spring Festival and it was held in the afternoon, attended by about sixty-year old women and the local miko. The women prayed for their families, especially for their grandchildren to be born safe and grow up healthy. Sometimes the local miko predicted the future; she would tell if there was some misfortune people should be warned about. The ritual that was held on August 23rd was called The Autumn Festival, while the ritual held on December 23rd was called The Jizō Festival and was conducted strictly at night. I found out that the ritual held on December 24th was called Jizo bon, better known as Urabon, which represented the continuation of the great Obon.

All these festivals are associated with the custom of visiting the graves of the deceased and the belief in their spirits visiting us on the specific occasions. These practices are accompanied with folk religious beliefs (divination, exorcism, belief in evil spirits, spirit possession) that continue in Japanese society even today. The fieldwork research made me realize how strongly the elements of folk religion are present in Jizo worship. I believe the presence of these elements is one of the reasons for Jizō's great popularity in Japan. In the following chapters I will try to put together some pieces of historical, theoretical, and axiological framework that might explain why such a specific attitude toward $J i z \bar{o}$ exists.

\section{Jizō in Sutras and Legends}

According to the written documents the name Jizō appears for the first time in the 8th century, while the first written sources and statues honoring him date from 9th century. Theorists do not agree about the timing of Jizös growth in popularity in Japan. Some claim that it happened at the end of the 9th century and in the 10th century, some place that time even earlier, and some say that Jizo was known in Heian period (he is mentioned in the women's diarist literature), but truly flourished only in the next, Kamakura period (1185-1333). Namely, 
the popularization of mappo doctrine happens during this period and Jizō, as one of the popular Bodhisattva, finds himself in a worthy position. ${ }^{3}$ This period was marked by numerous wars, violence and general insecurity. At times like these people seek a way out of earthly trouble and the rise of the popularity of Buddhism is not a surprise.

From the 7th century and onwards Chinese Buddhist clergy was increasingly interested in the world of hell, its geography, the articulation of torture and "bureaucracy" on which all this imaginary rested. This is a crucial moment, says Glassman (2012), in the formation of the context that forever linked Jizo to the underworld and its dark forces, although his role as a guardian of the human soul (which is held in China) was reduced to that of guardian of children's souls in Japan. His religious meanings in China will develop around the hell belief and the legend of the Buddha's disciple Mulian (Jap. Mokuren; Skt. Maugalyāyana), who descends to the underworld to rescue his mother from her posthumous sufferings. The story of Dizang or the Bodhisattva Jizō develops within the framework of the similar context. In the Dizang pusa benyuan jing (Jap.Jizō bosatsu bongankyō, Eng. Sutra of the Original Vow of Jizō Bodhisattva) we read of two past lives of Jizō, in which he, incarnated as a girl, saved his mother (ibid., 15-16).

In the first story he is incarnated as the daughter of a Brahmin family who lives in a distant cosmological period (Jap. zōhō), at the time after Buddha's death, when his light is attainable only through the holy books and presentations (pictures and statues) that embody him. The girl prays before the Buddha image and he responds to her with the promise that he will show her where her mother is and how to save her. However, the girl has to go home, sit down, and repeat his name three times. She does that, and her soul is transported into the Kingdom of Hell, where she meets a guardian who informs her that, thanks to her prayers and alms, her mother earned numerous merits, and is, therefore, moved from hell into heaven. But the sight of other souls in torment moves her so much that she decides to take a vow to do whatever it takes to save them and release them all from hell (Vettore 2010, 70).

In the second story Jizō also appears as Brahmin girl. The girl asks a clairvoyant monk to help her find her mother; he enters into a trance and discovers that she

3 Mappō is one of the Three Ages of Buddhism, significant to Mahayana adherents who believe that different Buddhist teachings are valid in each period due to the different capacity of the people to accept and understand these teachings. Mappō represents latter days of the law and the degeneration of the Dharma doctrine, in which people are incapable of following the Buddha teachings any more. They must wait for a new Buddha to be born (Jap. Maitreya, considered to be born millions of years in the future) to ensure the continuity of Buddhism. Until that time people should follow the teachings of different Bodhisattvas ("Buddha-to-be") and rely on their help and mercy. 
is suffering terribly. He asks the girl what her mother had done to be subjected to such a torture. She answers that she enjoyed too much food, especially fish and turtles, and thus had taken the lives of many living creatures. The monk instructs the girl to paint and carve numerous images of the Pure Lotus Eye Buddha and worship him by calling upon his name (Glassman 2012, 17).

This sutra probably originated in China, and therefore belongs to a group of socalled apocryphal texts, meaning that there is no clear evidence that the original Indian copy actually existed. Another text from the same group that played a big part in understanding of Jizō in Japan is Shiwang jing (Jap. Jūōkyō, Eng. Sutra of the Ten Kings). It tells the story of ten kings of hell and the path of the dead throughout their kingdoms. The most prominent is King Yama (Chin. Yanliwangwang or Yama, Jap. Enraō or Enmaō), the king that is met within the fifth week after the death (ibid., 18). In another (apocryphal) sutra named the Jizō Jūo Kyō or "The Sutra of Jizō and the Ten Kings" (composed in 13th century Japan) Jizō is equated with Enma, which can be understood as part of the doctrine honji suijak $u^{4}$ that equates Buddhist deities with the local ones. This sutra is about two foreign deities, but the doctrine itself is not exclusive and rigid, and it allows different combinations and interpretations. Both manifestations are two aspects of the same reality, which in this case means that Enma and Jizō in essence represent the same thing, just in different ways. According to Glassman $(2012,18)$ Jizō owes his immense popularity in medieval and early modern Japan in large part to the belief that Jizo is the best mediator between the sinner and the King Enma, since he, with his merciful and benevolent nature, represents the alter ego of this frightening judge.

In the 13th century the cult starts to truly flourish, as evidenced by the numerous statues and setsuwa stories about Jizō. Some of them are preserved in the large collections of setsuwa like Konjaku monogatarishü or Shasekishü, but the most important collection of such legends is certainly Jizō bosatsu reigenki ("Miraculous stories of Bodhisattva Jizo"). Most of these stories are related to a certain statue and the miraculous events connected with it. It is important to have in mind that it was believed then, that merely listening to the medieval religious narration could bring about good merits and assurance of, for example, the fulfillment of a certain romantic wish or a safe childbirth (ibid. 2012, 172).

4 The term honji suijaku refers to the idea that the Buddhist deities provisionally appear as Shintō kami in order to spiritually save sentient beings in Japan. The kami are thus the manifestations (suijaku; literally "traces"; i.e. the form appearing in the world to save sentient beings) of the Buddhist deities, and the Buddhist deities are the honji (literally "original ground") of the Shinto kami (namely, their true form and substance). Ultimately, the two entities are seen to form an indivisible relationship (Kawamura 2015). 


\section{Jizō and Sae No Kami}

Somewhere around the same time appears one of the Jizôs most representative iconographic form: Rokudo Jizō (six statues placed together in line, each for one level of human transition ${ }^{5}$ ). Many Japanese scholars argue that this is completely a Japanese product and that Jizo is found in this form only in Japan (Glassman $2012,27)$. Some theorists claim that this specific presentation of Jizo is the result of the influence of Japanese folk beliefs, even more because the sutras dedicated to the worship of the Six Jizōs are Japanese apocryphal texts, originated in Japan towards the end of the 12 th or the 13th century.

As statues are most often placed at large intersections, standing as the patrons of travelers (both in this and in the hereafter, through all six levels of human existence), the theorists connect them with sae no kami or sai no kami. "Sae" means "to block; to stop" and sae no kami are border deities. They are placed at the entrances to the villages because it is believed that they will protect them from evil spirits and negative forces. As we will see later in the text, they are mentioned in the Kojiki, where they stand at the borders of the world of the dead and the world of the living, but also between the sexes, and thus are associated with fertility and procreation. In addition to the patron deity of boundaries and fertility they are linked to the children (Bocking 1996, 146). Let us explain who these folk deities are and what their role is in the formation of $J i z \vec{o}$ s religious meanings.

The sae no kami, Japanese gods of sexuality and fertility, were from the beginning often represented in a phallic form. Phallic stones began to appear in Japan by the early Jomon period (about 10,000 BCE-300 BCE) and by the end of Jomon were quite widespread. Fudoki (local histories) show that these stones were meant to ensure fertility and safe childbirth. Archeologists have found extensive evidence from a very early period that the practice of marking village boundaries by stone pillars was also meant to ward off evil influences from outside the village. As some Japanese scholars suggested, the explosion of Jizös popularity in the early medieval period must be understood in the context of village cults that venerated sae no kami or dossojin; "road ancestor gods" (Glassman 2012,161). The process by which stone images of Jizō came to replace border stones and fertility images in villages throughout Japan showed that Jizôs popularity in the late medieval period and beyond was due primarily to assimilation with these ancient cults. It was his relationship with the gods of fertility that ultimately led to Jizō's modern identity as the patron saint of born and unborn children. In other words, ishigami or stone gods represent a very ancient layer of Japanese folk beliefs that were assimilated

5 Generally, there are six realms of samsara. These include: Gods, Asuras, Hungry Ghosts, Hell Beings, Animals, and Humans. 
with Buddhism during the medieval period through the figure of Jizō. It was through these stone images that people in Japan were able to incorporate foreign faiths and reconcile them with autochthonous practices (Glassman 2012, 162).

The cult of dosojin or sae kamie reaches deep into the past, when the most famous Japanese myths were formed. According the words of Kojima Yoshiyuki (cit. ibid., 167):

Among all the cults $(\operatorname{sink} \overline{0})$ of the Japanese people, the dōsojin are the most widespread and also the oldest. The character of the cult is various and complex, but its most basic aspects are that it seeks to ward off evil and that it bears similarities to the legend of Izanami and Izanagi. The identity of Izanami and Izanagi as the gods of union (musubi no kami) and the gods of couples ( $f \bar{u} f u$ no kami) is closely related to this connection of the dōsojin to the story of Izanami and Izanagi. The role of the dosojin as the gods of birth (osan no kami) and the gods of children (kodomo no kami) is no doubt a reflection of the narrative of the birthing of the land. Also, the fact that these gods are the first to demarcate the separation between the world of the living and the world of the dead reveals the close connection to the dōsojin of popular legend.

The earliest mention of the term sae no kami occurs in the Kojiki, in a scene where Izanagi descends into to the underworld of Yomi in pursuit of his wife after she died giving birth to their youngest child, the god of fire. By looking at her corpse, he breaks a taboo, doing what he has been explicitly warned against, and is chased from the land of the dead. After reaching safe grounds he drives a staff down into the ground, thus forming some kind of gate or barrier; this staff itself is called funato no kami and serves as a boundary marker between the land of the living and the land of the dead. The word funato, "the place at the fork in the road", was a slang for the sexual organs from as early as the Nara period (Glassman 2012, 167-9). This association comes from the similarity between an intersection or two roads connected diagonally and the relationship between the human torso and legs (ibid.).

Some scholars argue that when people disposed of their dead on hillsides, they often placed stone gods at the base of these hills to mark the separation between the world of the living and the world of the dead. So, it can be said that ishigami presided over birth as well as over death. These two functions of ishigami may seem to be at odds with one another, or at least unrelated, but the earliest records of worship of these gods make clear that the display of sexuality or the exposing of sexual organs was seen as the best way to drive away dark or evil influences and invite good fortune and blessings. 
As we have seen, Jizôs's connection with death and the underworld is obvious from the very beginnings, but from where does his connection with sexuality and birth come? It seems that that change came about during the medieval period when Jizō started to be experienced as ubugami or the deity of birth (Glassman 2012, 167). A similar process of identification that occurred with Jizo and sae no kamil dōsojin had already occurred with the yama no kami and ta no kami.

\section{Dōsojin and Yama No Kami}

During the introduction of agricultural techniques in the last centuries BCE, the travelers who reached Japan from Korea and China brought together with their agricultural knowledge their beliefs and rites. Among the Japanese nomadic hunters of that time it was customary to venerate the mountain deity (yama no kami) whom they believed to reside in the woods, and to place offerings on trees, the resting place of the deity. It is supposed that at some point the mountain deity was identified with the earth-god of the newcomers who had the knowledge of agriculture. So the mountain deity became the protector of farmers and was portrayed mostly in the form of a stone placed on a special holy site. The connection between foreign rites and the Japanese cult of yama no kami was made easy by the fact that the agricultural deity of the south Chinese area was a phallic earth-god, honored and bestowed with gifts in places within the woods, and was marked with a stone. A similar act of identification may have led to a similar process in the case of dosojin, since this deity was represented by a (phallic) stone from the very beginning (Naumann 1963, 349).

Let us examine more closely what kind of deity yama no kami was and what the possible associations with Jizō are. According to Bocking's "A Popular Dictionary of Shintō" (1996, 220), yama no kami is, as the very name suggests, a mountain god. He has two meanings: one pertains to the deity worshipped by those working in mountain areas (traditionally hunters, charcoal-burners, and woodcutters), and in this case identified with Oyamatsumi or Kono hana saku ya bime. In its other meaning yama no kami denotes the deity of agriculture and growth, who descends from the mountain at a specific time and is worshipped as ta no kami or the $\operatorname{god}^{6}$ of the rice fields.

6 Ta no kami: "The kami of rice fields, i.e. kami of agriculture, known throughout Japan under various names; in Tōhokunōgami, in Nakano and Yamanashi sakugami, in the Kyōto-Ōsaka area tsukuri-kami, in the Inland Sea jigami, in Kyūshū ushigami. Ta-no-kami is generally thought to descend from heaven or the mountains in the spring and to return in the autumn, and is often identified with yama no kami. In Eastern Japan ta no kami may be identified with Ebisu, and in the west with Daikoku.” (Bocking 1996, 199) 
Yama no kami is a severe deity, who does not give in easily to the prayers of the hunters, or any others who dared to violate the unwritten laws of the woods, by punishing them and inflicting them with diseases and even death. In order to guarantee the deity's goodwill, the people must maintain the purity of the rituals and use the special language (the "mountain language") as soon as they enter the woods (Naumann 1963, 342-3).

There was the belief that the mountain deity dwelt or rested upon certain kinds of tree that were forbidden to be felled. Nearly everywhere in Japan it was believed that on a fixed date in autumn the mountain deity went through the woods to collect the seeds of the various trees. On a certain day in spring, he went to the woods again to sow those seeds and to protect the growth of the trees. It can be concluded that the mountain deity is also in some way the creator and the preserver of the woods (ibid., 343).

Independently of the trees of the mountain-deity, it was believed in the past that many trees possessed $t a m a^{7}$ and were, therefore, worshiped as gods. The concept of "tree spirits" is very often connected with the belief that spirits of the dead dwell in the woods in the mountains or on nearby trees. People prayed to those trees for recovery from illness and for an easy delivery, for lucky marriage and for offspring. The same prayers were offered to the mountain deity. The conception of yama no kami as a helper in childbirth has its roots in the belief that he brings from the woods the soul of the child waiting to be born. This soul is nothing but the spirit of an ancestor who died years ago and was dwelling in the woods purifying itself and thus losing its former individuality (ibid., 343-4).

At the beginning of the New Year there it was customary to cut some small trees or branches and to bring them home, where they were used in many ways, mainly for praying for a good harvest. This custom of cutting down trees and branches on New Year's seems to be connected with the conception that yama no kami himself descends from the woods to live for half the year in the fields to become ta no kami, the field-deity. Some scholars pointed out that this ta no kami is actually a deity of the same origin and characteristics as yama no kami (ibid., 344).

7 The most common meaning of tama in the Shintō context (also pronounced "rei") means soul or spirit. Tama is an entity that resides in something to which it gives life and vitality, whether this is human, animal, or a natural feature. Disembodied, the tama may be a kami or aspect of a kami, or a spirit of an ancestor or other dead person. (Bocking 1996, 197)

8 Ta no kami may also be equated with Jigami: Land kami. "A term used in Western Japan, similar to jinushigami or tochigami. It refers to the enshrined spirit of a village founder or one who first cultivates the land in a particular area. The shrine is usually located in a corner or on the border of a field. In some cases ancestors are thought to become jigami". (Bocking 1996, 69) 
The alternating status of this deity had its roots in the belief in the so-called marebito, i.e. gods or ancestor-souls visiting the homes of the living on certain days (New Year's, Bon festival, or after the harvest). Actually, mountain-deity is nothing but the soul of an ancestor. This opinion became prevalent because the mountain deity was often identified with the year-god, who came down from the mountains on New Years's Day, bringing good luck and prosperity and declaring himself to be the soul of an ancestor (Naumann 1963, 345).

Marebito are defined as "supernatural guests", usually the spirits of ancestors, who arrive from tokoyo, a miraculous land from across the sea, to enrich the land with new power for the new year. ${ }^{10}$ They are part of a "horizontal" cosmological structure in which kami, like ancestral spirits during bon, are believed to come from, or return to a faraway land or across the sea, rather than from another world above or below this one. ${ }^{11}$ Boundary deities (sae no kami etc), as well as deities of good fortune as Ebisu and Daikoku, also belong in the general category of marebito as deities who come "from the outside" and are invoked for special purposes" (Bocking 1996, 115).

What we see is that the mountain deity has healing powers, helps in childbirth, brings prosperity, and operates as marebito, the spirit of an ancestor.

Naumann points out that there is a striking resemblance between the rituals (feasts) of the mountain deity and those of the gods of roads that could lead to the supposition of one identity of the two gods. In ancient times the mountain deity was the protector of mountain roads and passes, and the deity of roads was the protector against evil spirits lurking at the boundaries between the world of the living and the world of the dead, and was, therefore, posted at all spots that were haunted by such spirits, i.e. cross-roads, bridges, village boundaries, etc. (Naumann 1963, 346).

9 Tokoyo: "Eternal land, tokoyo no kuni. Another-world, either across the sea or a realm of its own beneath the water, equated with the dragon's palace, ryūg $\bar{u}$, inhabited by beneficent and demanding spirits including spirits of the dead and particularly transforming snakes. Inland, Tokoyo came to be located in the mountains rather than the sea, forming the other-world of mountains which, combined with Buddhist cosmology, was the basis of mountain religion (shugendo, yama no kami)." (Bocking 1996, 205)

10 Remnants of belief in marebito survive in folk dances and mimes and they share some characteristics of the horned, straw-coated namahage of northern Japan and the toshidon of the south.

11 On the other side there is the concept of Takamagahara: "The Plain of High Heaven, the other world from which the heavenly kami descend. It is the upper realm in a "vertical" cosmology comprising high heaven, this human world and yomi, the lower realm of the dead. The notion widespread since Meiji era that emperor was descended from the kami of takamagahara derived from the rediscovered "classic" mythologies of the Kojiki and the Nihongi (kokugaku, kokkashintō), even though the traditional cosmology of shrine worship overwhelmingly refers to kami who live in this world or come from montains (yama no kami), over the horizon or under the sea (tokoyo, marebito, ryūgü)." (Bocking 1996, 195) 
The feast of the mountain deity was mainly celebrated within the first month of the year and especially around the 15th day or around the winter solstice (former month 11), and was often accompanied by certain features of feasts celebrated at about same time in honor of the dosojin, the gods of roads. Those feasts were illuminated with bonfires and represented phallic vegetation rites, ritual laughing, rope-pulling and contests for divination of the crops. These features, though mostly connected with yama no kami and dosojin, are also observed in Shinto shrines and some Buddhist temples, but it is evident that the connection with these deities is only a secondary one. (Naumann 1963, 346)

\section{The Secondary Connections with Yama No Kami Cult}

Naumann $(1963,348)$ notices a whole range of similar rituals in Japan, Korea, and South China at approximately the same time of the year, namely:

- Japan: The whole complex of customs and beliefs connected only secondary with yama no kami consisted of feasts celebrated chiefly around the 15 th day of the first lunar month, which is the day of the full moon called the "Minor New year" (and maybe in former times marking the beginning of the year), and sometimes of a corresponding feast in autumn or winter (such as the Bon festival or a feast around the winter solstice). These feasts were defined by the belief in the spirits of the dead visiting the living, by rites of expelling evil (bonfires) and of invocation of fertility (phallic vegetation rites), by contests between local groups for divination of crops (rope-pulling, stonefights), and by fetching and sending the gods to preside over agriculture (mainly yama no kami).

- Korea: There was a custom of burying the dead in the mountains, where it was believed the souls of the dead dwelt. We notice that there were feasts on January and July 15th, based on the belief of the spirits of the dead visiting the living, mountain climbing with torches, rites of expelling evil, contests between local groups (rope-pulling, stone-fights), and the descent of the mountain deity down into the village shrine on April 15th:

- South China: The same feasts held on January and July 15th (or during the days of equinoxes), were characterized by the visit of the spirits of the dead, by the rites of expelling evil (bonfires), by promoting fertility (phallic vegetation rites), by contests between local groups (rope-pulling, stone-fights), and by invoking the gods to send rain and, therefore, to provide fertility (dragon) (ibid., 348). 
In my opinion, Jizō matsuri, whose traces I witnessed in Yamagata prefecture, cannot be anything but one of these secondary connections with previous popular traditions. It was held on April, August, and December 23rd, the date connected with the custom of visiting the graves of the deceased during the lunar spring and autumn equinox (March 23rd and September 23rd). It was also associated with the belief in dead ancestor's spirits visiting us on specific occasions. These rituals, as I mentioned, were accompanied by various folk religious practices and beliefs (participation of the local miko, divination, exorcism, spirit possession).

\section{Conclusion}

With the exception of the temples, Jizo is most commonly encountered at road crossings, village boundaries, and graveyard entrances, where he stands as a protector of travelers, both in this and in the "other world". His liminal position in both a physical and metaphysical sense has been associated with the very ancient folk beliefs that are thought to have influenced the formation of Jizôs cosmogony and whose traces can still be seen all over Japan. These beliefs are linked to sae no kami and dōsojin, gods of boundaries and roads, to Japanese folk deities associated with fertility and sexuality that have evoked prosperity and wealth. From the ancient times they were placed at village and cemetery entrances and near crossroads, and it is considered that Jizō took over their ancient role.

The Japanese and other East Asian peoples buried their dead in the hills. They placed stone statues (ishigami) at their bases to mark the boundary between the world of the dead and the world of the living. In this way, sae no kami and dosojin happened to rule not only in the realm of fertility and procreation, but also in the realm of death. At first glance these two functions may seem rather incompatible, but since ancient times the presentation of sexuality in some form was one of the ways of the struggle against evil and undesirable forces, as much as it was a way of evoking happiness and prosperity. In this way, Jizo, who was at first associated with death and the underworld, begins to replace the folk deities in the Middle Ages and the new change in meaning brings about the connection with reproduction and birth.

If we look much further back in time from the ages when the Japanese myths were formulated, we will encounter yama no kami, the Japanese god of mountains. This god was identified with the god of fertility of the newcomers after the introduction of agriculture technique in Japan. The Japanese guardian of the souls of the dead, who accompanied them back to the world of the living, was now turned into the god of fertility, food, and prosperity (ta no kami). In other 
words, a similar process of assimilation that occurred with Jizō (foreign element) and sae no kami/dosojin (domestic element) had already occurred with the yama no kami and ta no kami.

According to Bocking's A Popular Dictionary of Shinto (1996) Yama no kami, Ta no kami, Sae no kami, Ebisu and Daikoku belong to the category of marebito or the deities that come "from the outside" when the ground needs to be showered with the special gifts. In their essence they are nothing but ghosts of the ancestors coming from the country over the horizon ${ }^{12}$ or above the sea at the particular time of the year. Jizō matsuri in Yamagata continued this tradition occurring during the spring and autumn equinox (March 23rd and September 23rd), today dates reserved for the visiting the graves of the deceased.

The process by which stone statues of Jizo replaced the stone statues of sae no kamija and dösojina illustrates well how Buddhism, as an imported religion, manipulated the existing customs and beliefs and used them to gain acceptance among ordinary people. His association with native gods of fertility and reproduction eventually brought him toward his modern identity as protector of the unborn or the children that died prematurely. But Jizo did not adopt this identity right after his arrival in Japan. This reversal occurred in the Middle Ages, sometime during Muromachi period (1338-1573). Until that time he was, just like in China, the god of the underworld and the protector of the spirits of the dead, especially the biggest sinners who ended up in hell. The historical and social circumstances that led to this reversal are in the process of investigation, but what we can say for sure is, that during the Muromachi and Edo periods there was an increased interest in the legends and the miraculous stories of Jizo. Also, during this period we see a formulation of the Sai no kawara concept or the place on the riverbank where the souls of the dead children reside. This process will ultimately result in the belief of mizuko (spirits of the dead children) as goryo or evil spirits, and also in the emergence of Mizuko Jizo, although we know that there is no trace of vengeful evil spirits in the original Buddhist texts nor can we find that Bodhisattva Jizō was dedicated exclusively to them. What we witness is another manipulation of meanings with the intent of promoting Buddhism and adapting it for the spiritual needs of women in modern times, and also for having a significant commercial impact.

The Jizō Bodhisattva amalgamation does a good job of illustrating how Buddhism adapted to the needs of Japanese people through history. But it also shows the

12 This horizontal view of human existence is an ancient Japanese view that does not recognize the "other world" above us (heaven) or beneath us (underworld), but sees it as part of our own world and not as something that can be separated from it. 
persistence of attitude Japanese people have toward their popular folk deities and beliefs. The popularity of Jizo is closely connected with his associations to these deities. The attitude of the Japanese towards Jizō, the fact that they feel closeness and familiarity versus his figure, is determined by his conceptual interweaving with dösojina and sae no kami. Jizō is actually worshiped in the manner of ancient Japanese folk deities, even though he is a Buddhist by tradition.

\section{References}

Blocking, Brian. 1996. A Popular Dictionary of Shinto. Richmond: Curzon Press. De Visser, Marinus Willem 1912. The Bodhisattva Ti-Tsang (Jizō) in China and Japan. Berlin: Oesterheld \& Co.

Glassman, Hank. 2012. The face of Jizo.. Image and Cult in Medieval Japanese Buddhism. Honolulu: University of Hawaii Press.

Jauk Pinhak, Milka. 2001. Buddhizam i đinizam. Istočne religije. Skripta za Studente, 85-140. Zagreb: Filozofski fakultet, Katedra za indologiju.

Kawamura, Kunimutsu. 2015. "Sakainokami." In Encyclopedia of Shinto.

Accessed November 9, 2015. http://eos.kokugakuin.ac.jp/modules/xwords/ entry.php?entryID=225.

Lakić Parać, Iva. 2007. "Higashihorikoshi wo chūshin to suru Jizō shinkō.”

Fieldwork paper. 2006 Ethnology of Hagurosan. Yamagata prefecture, The

City of Furuoka, 23-29. Department of Ethnology, University of Tsukuba.

Naumann, Nelly. 1963. Yama no kami-die japanische Berggottheit. Teil I:

Grundvorstellungen." Asian Folklore Studies 22, S. 133-366. Accessed

September 9, 2015. https://nirc.nanzan-u.ac.jp/nfile/568.

Tamaru, Noriyoshi, and David Reid, eds. 1996. Religion in Japanese Culture.

Where Living Traditions Meet a Changing World. Tokyo, New York, London:

Kodansha International.

Vettore, Caterina. 2010. “Il Bavaglino Rosso.” La Ricerca Folclorica 62: 69-78.

Vestire i simulacra. 